\title{
PEMETAAN DAERAH BERPOTENSI TRANSMIGRAN DI KECAMATAN KARTASURA DENGAN METODE FUZZY C-MEANS (FCM) CLUSTERING
}

\author{
Mawar Hardiyanti ${ }^{1)}$; Yustina Retno Wahyu Utami ${ }^{2}$; Wawan Laksito Yuly Saptomo ${ }^{3)}$ \\ 1)2)3) Program Studi Teknik Informatika, STMIK Sinar Nusantara \\ ${ }^{1)}$ mawar120295@gmail.com; ${ }^{2)}$ yustina_retno@sinus.ac.id; ${ }^{3)}$ wlaksito@sinus.ac.id
}

\begin{abstract}
In an attempt to achieve the well-being of Indonesia, one of the Government's policies that need to be implemented are the deployment and implementation of the transmigration program. In General only a transmigration program offered by the Government to all societies without knowing the economic background and his family so that the transmigration program was not right on target. Based on the background of the problems in this research is how to design, build, develop and implement Fuzzy C-Means Clustering on Regional Mapping System for classifying the area potentially Homesteader in Kartasura. The data obtained by conducting interviews at the population administration of the subdistrict of Kartasura, observation and study of the literature. In this research, the author uses secondary data. Data obtained from Reports in Kartasura Subdistrict number 2015 by BPS (Statistics Indonesia) Sukoharjo Regency. The results obtained are Fuzzy C-Means method can be applied to a system of mapping the area potentially Homesteader in Kartasura can optimize the work of the Government in the implementation of the resettlement program. Testing the cluster with Center validation methods using MPC alternate data criteria in the period the year 2014 and 2015 which States that 3 clusters are the cluster validation.
\end{abstract}

Keywords: Classification, Fuzzy C-Means, Transmigration

\section{PENDAHULUAN}

Paradigma baru yang sudah jauh berbeda dengan paradigma lama, terjadi dengan dikeluarkannya undang-undang No. 5/1997. Pelaksanaan transmigrasi tidak lagi difokuskan pada pemecahan masalah persebaran penduduk, yang selama 90 tahun terakhir memang tidak berhasil dipecahkan, namun bergeser pada pengembangan ekonomi dan pembangunan daerah. Dalam undang-undang tersebut dinyatakan, bahwa tujuan transmigrasi adalah,untuk meningkatkan kesejahteraan transmigran dan masyarakat sekitar,meningkatkan pemerataan pembangunan daerah, dan memperkuat persatuan dan kesatuan bangsa. Oleh karena itu sudah selayaknya pemerintah mengkaji potensi yang dimiliki calon transmigran baik dari segi kualitas sumberdaya manusia, ekonomi, sosial maupun budaya.

Di samping itu potensi yang dimiliki wilayah penempatan transmigrasi harus diinformasikan kepada para calon transmigran sehingga terjadilah kesesuaian antara potensi calon transmigran dengan potensi wilayah penempatan. Implikasi dari kebijakan ini diharapkan dapat menjadi daya menarik penduduk di daerah padat dan berpendidikan relatif tinggi untuk bersedia bermigrasi ke daerah baru tersebut. Berdasarkan hal tersebut maka dilakukan penelitian dengan tujuan adalah menganalisis potensi calon transmigransasaran pengarahan dan perpindahan di daerah asal, dan mengakaji prosedur teknis pelaksanaan pengarahan dan perpindahan calon transmigran[1].

Permasalahan yang terjadi dikantor Kecamatan Kartasura yaitu sistem yang berjalan masih menggunakan sistem manual, dimana sistem yang berjalan pada program transmigrasi selama ini hanya ditawarkan ke semua penduduk melalui para ketua RT dan RW setempat pada saat rapat / kumpulan. Dan hasil dari sistem menawarkan kepada semua orang yang mungkin tidak perlu melakukan transmigrasi, sedangkan pemerintah sendiri seharusnya melakukan perhitungan dimana daerah yang berpotensi untuk ditawarkan transmigrasi. Sehingga di Kecamatan Kartasura diperlukan sebuah sistem guna mendukung pengembangan program transmigrasi serta mempermudah pemerintah dalam menawarkan program transmigrasi pada sasaran atau penduduk yang tepat atau daerah berpotensi transmigran. Variabel penelitian adalah data kependudukan pada 12 Desa di Kecamatan Kartasura. Variabel tersebut mencakup angka kelahiran, angka 
kematian, jumlah pendatang, maupun jumlah warga yang berdomisili disitu.

Pemetaan digunakan sebagai alat peraga untuk menyajikan informasi pada suatu wilayah yang mengandung informasi yang disampaikan kepada pengguna dengan menggunakan data - data yang valid. Begitu juga pemetaan daerah berpotensi transmigran.

\section{TINJAUAN PUSTAKA}

\subsection{Penelitian Sebelumnya}

Dalam pemetaan, pengelompokan data dan transmigran. Dalam penelitian sebelumnya terdapat jurnal yang ditetili oleh Sudrajat yang berjudul Analisis potensi calon transmigran sasaran pengarahan dan perpindahan [1] didapatkan hasil penelitian juga menunjukkan bahwa prosedur dan penjangkauan informasi masih ada beberapakelemahan, terutama terkait dengan sosialisasi program transmigrasi melalui berbagai media komunikasi masih kurang sehingga informasi yang tidak dapat diterima olehmasyarakat. Alvian Kusuma Wijaya yang berjudul Implementasi Data Mining dengan Algoritma Fuzzy C-Means Studi Kasus Penjualan di UD Subur Baru [2] dijelaskan bahwa metode Fuzzy C-Means dapat mempermudah UD Subur Baru untuk mengidentifikasi tingkat penjualan produkberdasarkan tiga tingkatan yaitu sangat laku, laku dan kurang laku. Selain itu dilihat dari penelitian yang lain yang diteliti oleh Hanifa Setianingrum yang berjudul Model Pemetaan Evaluasi Penilaian Kualifikasi Lulusan Berbasis Metode Fuzzy C-Means Clustering [3] dijelaskan bahwa metode Fuzzy C-Means dapat mempermudah menentukan cara pembelajaran kepada mahasiswa dengan mengidentifikasi kualifikasi kelulusan dengan standar SKKNI.

Dalam penelitian internasional pada jurnal yang diteliti oleh Martin J. Bunch, T.Vasantha Kumara, R.Joseph yang berjudul Using Geographic Information System (GIS) For Spatial Planning and Environmental Management in India; Critical Considerations [4] dijelaskan bahwa penggunaan GIS di program penelitian pengelolaan lingkungan hidup di Sungai Cooum di Chennai yang berperan untuk perencanaan pengelolaan lingkungan hidup. Selain itu dapat dilihat dari Implementation Of The Fuzzy C-Means Clustering Algorithm, Meteorologi Data[5]dijelaskan bahwa Perhitungan metode Fuzzy C-Means yang dibandingkan perhitungan dengan metode K-Means yang lebih cepat digunakan untuk menghitung dan dengan kesalahan yang minimum.

Berdasarkan masalah yang terurai diatas maka akan dibuat aplikasi pemetaan daerah transmigran di Kecamatan Kartasura dengan Metode Fuzzy C-Means (FCM) Clustering untuk mempermudah Administrasi Kependudukan dalam mengklasifikasi daerah berpotensi transmigran di Kecamatan Kartasura.

\subsection{Pemetaan}

Peta adalah penggambaran dua dimensi pada bidang datar keseluruhan atau sebagian dari permukaan bumi yang diproyeksikan dengan perbandingan atau skala tertentu[6].

Pemetaan merupakan proses pengumpulan data untuk dijadikan sebagai langkah awal dalam pembuatan peta, dengan menggambarkan penyebaran kondisi alamiah tertentu secara meruang, memindahkan keadaan sesungguhnya kedalam peta dasar, yang dinyatakan dengan penggunaan skala peta.

\subsection{Transmigrasi}

Program transmigrasi atau perpindahan penduduk sebetulnya telah dikenal pada masa pemerintahan kolonial Belanda dan lebih dikenal dengan istilah kolonisasi[7]. Syarat syarat untuk menjadi transmigran yaitu: Warga Negara Indonesia; Bertaqwa kepada Tuhan Yang Maha Esa; Telah berkeluarga yang dibuktikan dengan Surat Nikah, KTP dan Kartu Keluarga; Berusia $19 \mathrm{~s} / \mathrm{d} 50$ th (Usia Produktif); Berbadan sehat Jasmani dan Rohani; Memiliki keahlian/ketrampilan sesuai kebutuhan daerah penempatan; rekomendasi/ legalitas dari Kepala Desa, Camat, dan Kepolisian Setempat; Menandatangani surat pernyataan kesanggupan melaksanakan kewajiban sebagai transmigran dan mentaati peraturan sesuai dengan ketentuan yang berlaku.

\subsection{Fuzzy C-Means}

Pada penelitian ini, metode analisis data yang digunakan adalah fuzzy c-means (FCM). FCM adalah suatu teknik pengclusteran data yang keberadaan tiap-tiap titik data suatu cluster ditentukan oleh nilai keanggotaan[8].

Kelebihan metode FCM adalah penempatan pusat cluster yang lebih tepat dibandingkan dengan metode cluster lain. Algoritma dari fuzzy c-means adalah sebagai berikut [9]: 
1. Menginput data yang akan dikelompokan, yaitu $\mathrm{X}$ berupa matriks berukuran $\mathrm{n} \times \mathrm{m}(\mathrm{n}=$ jumlah sampel data, $m=$ atribut setiap data). $X_{i j}$ data sampel ke-i $(i=1,2, \ldots, n)$, atribut ke-j $(j=1,2, \ldots, m)$.

2. Menentukan jumlah cluster (c), pangkat untuk matriks partisi (w), maksimum iterasi (Maxlter), error terkecil yang diharapkan $(\varepsilon)$, fungsi objektif awal $\left(P_{0}=0\right)$, dan iterasi awal $(t=1)$.

3. Membangkitkan bilangan random $\mu_{\mathrm{ik}}$, $i=1,2, \ldots, n ; \quad k=1,2, \ldots, c$ sebagai elemen matriks partisi awal $U$.

Menghitung jumlah setiap kolom yang dapat dilihat dalam persamaan (1) dan (2):

$$
Q_{i}=\sum_{k=1}^{c} \mu_{i k}
$$

Dengan $\mathrm{j}=1,2, \ldots, \mathrm{n}$.

Menghitung :

$$
\mu_{j k}=\frac{\mu_{i k}}{Q_{i}} \text {. }
$$

4. Menghitung pusat cluster ke-k: $\mathrm{V}_{\mathrm{kj}}$, dengan $\mathrm{k}=1,2, \ldots, \mathrm{C} ;$ dan $\mathrm{j}=1,2, \ldots, \mathrm{m}$, menggunakan persamaan (3) :

$$
V_{k j}=\frac{\sum_{i=1}^{n}\left(\left(\mu_{i k}\right)^{w} \cdot X_{i j}\right)}{\sum_{i=1}^{n}\left(\mu_{i k}\right)^{w}}
$$

$\mathrm{V}_{k j}=$ pusat cluster ke-k untuk atribut ke-j

$\mathrm{V}_{i k}=$ derajat keanggotaan untuk data sampel ke-i pada cluster ke-k

$\mathrm{V}_{i j}=$ data ke-i, atribut ke-j

5. Menghitung fungsi objektif pada iterasi ke-t menggunakan persamaan (4):

$$
P t=\sum_{i=1}^{n} \sum_{k=1}^{c}\left(\left[\sum_{j=1}^{m}\left(X_{i j}-V_{k j}\right)^{2}\right]\left(\mu_{i k}\right)^{w}\right.
$$

dengan :

$\mathrm{V}_{\mathrm{kj}}=$ pusat cluster ke-k untuk atribut ke-j

$\mu_{i k}=$ derajat keanggotaan untuk data

sampel ke-i pada cluster ke-k

$\mathrm{X}_{i=}=$ data ke-i, atribut ke-j

$\mathrm{P}_{\mathrm{t}}=$ fungsi objektif pada iterasi ke-t

6. Menghitung perubahan matriks partisi menggunakan persamaan (5):

$$
\mu_{i k}=\frac{\left[\sum_{j=1}^{m}\left(X_{i j}-V_{k j}\right)^{2}\right]^{\frac{-1}{w-1}}}{\sum_{k=1}^{c}\left[\sum_{j=1}^{m}\left(X_{i j}-V_{k j}\right)^{2}\right]^{\frac{-1}{w-1}}} \ldots
$$

dengan $\mathrm{i}=1,2, \ldots, \mathrm{n}$; dan $\mathrm{k}=1,2, \ldots, \mathrm{c}$

Dimana:

$\mathrm{V}_{\mathrm{kj}}=$ pusat cluster ke-k untuk atribut ke-j

$\mathrm{X}_{i j}=$ data ke-i, atribut ke-j

$\mu_{i k}=$ derajat keanggotaan untuk data sampel ke-i pada cluster ke - $\mathrm{k}$

7. Mengecek kondisi berhenti :
Jika : $\left(\left|\mathrm{P}_{\mathrm{t}}-P_{t-1}\right|<-\varepsilon\right)$ atau (t $>$ Maxlter) maka berhenti. Jika tidak : $\mathrm{t}=\mathrm{t}+1$, ulangi langkah ke-4

\section{METODE PENELITIAN}

Pengembangan sistem merupakan tahapan penulis merancang alur - alur program yang digunakan berdasarkan kebutuhan sistem dengan menggunakan metode waterfall. Metode waterfall adalah model klasik yang bersifat sistematis, berurutan dalam membangun software [10].

\subsection{Penelitian Sebelumnya}

Untuk kesempurnaan sistem yang akan dibuat, maka data yang digunakan harus data yang akurat dan tepat. Pada penelitian ini, penulis menggunakan data sekunder. Data didapat dari jurnal Kartasura dalam angka 2015 oleh BPS (Badan Pusat Statistik). Selain itu, penelitian ini menggunakan metode pengumpulkan data pustaka. Data diambil dari mempelajari buku refrensi, mencari sumber yang berkaitan dengan penelitian baik dari internet maupun jurnal.

\subsection{Data Alternatif dan Kriteria}

Data yang dijadikan sebagai data kriteria yaitu data jumlah kepadatan penduduk, data jumlah pasangan usia subur (PUS) dan data jumlah keluarga kurangmampu. Sedangkan data alternatif adalah data 12 Desa di Kecamatan Kartasura.

\subsection{Perhitungan Fuzzy C-Means}

Pertama menyiapkan data kriteria dan alteratif terlebih dahulu. Data kemudian diolah dan dibagi menjadi 3 cluster yaitu daerah kurang berpotensi, berpotensi dan sangat berpotensi transmigran.

\section{HASIL DAN PEMBAHASAN}

Sistem yang dikembangkan difokuskan pada pengelompokkan daerah berpotensi transmigran guna membantu kerja pemerintah untuk menentukan daerah calon transmigran yang tepat.

Pengelompokan daerah berpotensi transmigran menggunakan kriteria kepadatan penduduk, PUS ( Pasangan Usia Subur ), dan Keluarga kurang mampu. Dalam perhitungannya fuzzy c-means daerah berpotensi transmigran di Kartasura dapat dilihat pada aliran perhitungan dengan menggunakan flowchart Gambar 1. 


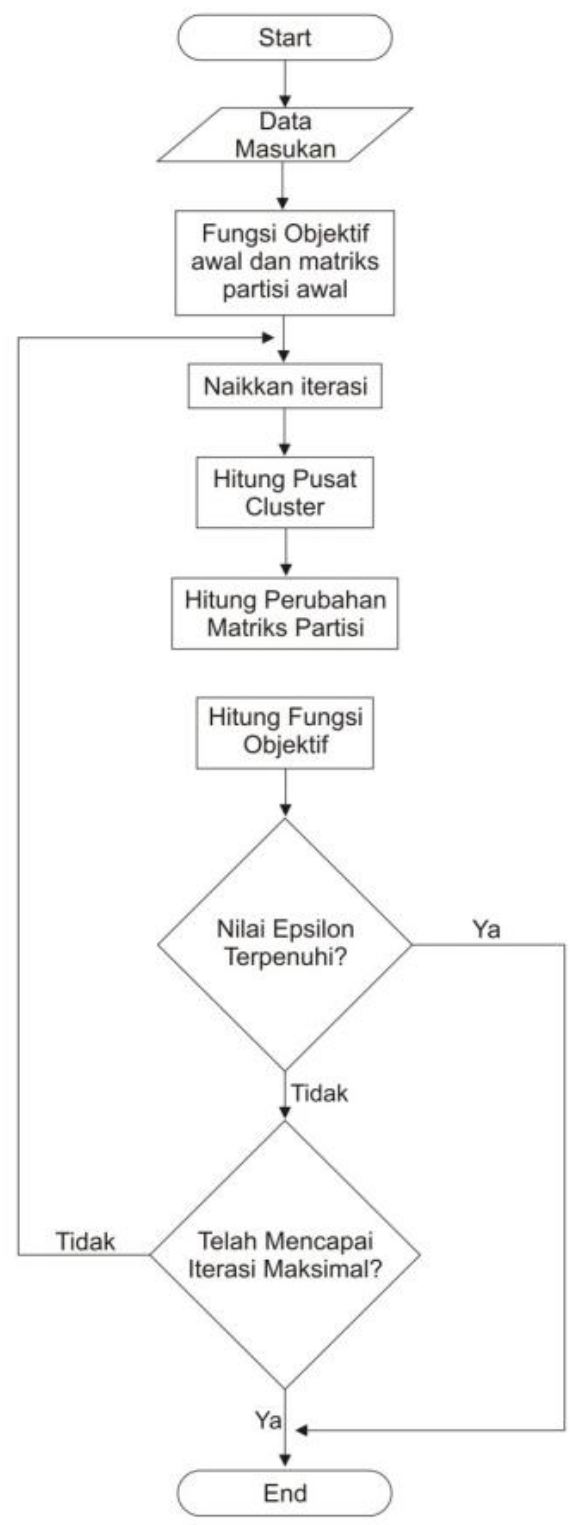

Gambar 1. Flowchart Fuzzy C-Means Clustering

Proses clustering menggunakan algoritma FCM. Proses clustering dilakukan dengan menetapkan nilai awal sebagai berikut: 1. Jumlah cluster yang akan dibentuk = 3 yaitu daerah yang sangat berpotensi transmigran, derah yang berpotensi transmigran dan daerah yang kuang berpotensi transmigran.

2. Pangkat pembobot $=2$

3. Kriteria penghentian $=0,000001$

4. Fungsi objektif awal $=0$

5. Nilai iterasi awal $=1$

Langkah pertama perhitungan Fuzzy $C$ Means yaitu menentukan derajat keanggotaan melalui matrik partisi $U$ yang dibentuk secara random. Matrik partisi $U$ dapat dilihat pada Tabel 1.
Tabel 1. Matrik partisi U

\begin{tabular}{|r|l|r|r|r|r|r|r|}
\hline \multirow{2}{*}{ No } & \multirow{2}{*}{ Desa } & \multicolumn{4}{|c|}{ Alternatif Kriteria $\left(X_{j}\right)$} & \multicolumn{3}{|c|}{$\begin{array}{c}\text { Keanggotaan } \\
\text { Cluster }(\mu)\end{array}$} \\
\cline { 3 - 9 }$(\mathrm{X} 1)$ & $\begin{array}{r}\text { Kepadatan } \\
(\mathrm{X} 2)\end{array}$ & $\begin{array}{c}\text { Krg Mampu } \\
(\mathrm{X} 3)\end{array}$ & $\mathrm{C} 1$ & $\mathrm{C} 2$ & $\mathrm{C} 3$ \\
\hline 1 & Ngemplak & 2060 & 653 & 358 & 0,3 & 0,3 & 0,4 \\
\hline 2 & Gumpang & 3883 & 1526 & 780 & 0,3 & 0,5 & 0,2 \\
\hline 3 & Makamhaji & 7567 & 2257 & 682 & 0,8 & 0,1 & 0,1 \\
\hline 4 & Pabelan & 2927 & 1217 & 1163 & 0,5 & 0,2 & 0,3 \\
\hline 5 & Ngadirejo & 8022 & 1368 & 447 & 0,5 & 0,1 & 0,4 \\
\hline 6 & Kartasura & 11460 & 2058 & 426 & 0,2 & 0,1 & 0,7 \\
\hline 7 & Pucangan & 5983 & 2124 & 835 & 0,3 & 0,4 & 0,3 \\
\hline 8 & Kertonatan & 2911 & 719 & 367 & 0,6 & 0,2 & 0,2 \\
\hline 9 & Wirogunan & 3089 & 783 & 262 & 0,4 & 0,2 & 0,4 \\
\hline 10 & Ngabeyan & 3726 & 850 & 232 & 0,2 & 0,3 & 0,5 \\
\hline 11 & Singopuran & 5026 & 972 & 311 & 0,1 & 0,6 & 0,3 \\
\hline 12 & Gonilan & 3592 & 945 & 251 & 0,1 & 0,5 & 0,4 \\
\hline
\end{tabular}

Kemudian menghitung miu kuadrat yang diperoleh dari derajat keanggotaan. Selanjutnya dikalikan dengan nilai $X$ atau alternatif kriteria yang ada. Perhitungan miu kuadrat dapat dilihat pada Tabel 2 dan Tabel 3.

Tabel 2. Miu Kuadrat Atribut Kepadatan Penduduk dan PUS

\begin{tabular}{|c|c|c|c|c|c|c|c|c|}
\hline \multirow{3}{*}{$\begin{array}{r}\text { No } \\
1\end{array}$} & \multicolumn{2}{|c|}{$\mu 2$} & \multirow{2}{*}{\multicolumn{3}{|c|}{ Miu Kuadrat $X 1\left(\mu^{2} * X_{1}\right)$}} & \multirow{2}{*}{\multicolumn{3}{|c|}{ Miu Kuadrat $X 2\left(\mu^{2} * X_{2}\right)$}} \\
\hline & $\mathrm{C} 1$ & $\mathrm{C} 2$ & & & & & & \\
\hline & 0,09 & 0,09 & 185,4 & 58,77 & 32,22 & 185,4 & 58,77 & 32,22 \\
\hline 2 & 0,09 & 0,25 & 349,47 & 137,34 & 70,2 & 970,75 & 381,5 & 195 \\
\hline 3 & 0,64 & 0,01 & 4842,88 & 1444,48 & 436,48 & 75,67 & 22,57 & 6,82 \\
\hline 4 & 0,25 & 0,04 & 731,75 & 304,25 & 290,75 & 117,08 & 48,68 & 46,52 \\
\hline 5 & 0,25 & 0,01 & 2005,5 & 342 & 111,75 & 80,22 & 13,68 & 4,47 \\
\hline 6 & 0,04 & 0,01 & 458,4 & 82,32 & 17,04 & 114,6 & 20,58 & 4,26 \\
\hline 7 & 0,09 & 0,16 & 538,47 & 191,16 & 75,15 & 957,28 & 339,84 & 133,6 \\
\hline 8 & 0,36 & 0,04 & 1047,96 & 258,84 & 132,12 & 116,44 & 28,76 & 14,68 \\
\hline 9 & 0,16 & 0,04 & 494,24 & 125,28 & 41,92 & 123,56 & 31,32 & 10,48 \\
\hline 10 & 0,04 & 0,09 & 149,04 & 34 & 9,28 & 335,34 & 76,5 & 20,88 \\
\hline 11 & 0,01 & 0,36 & 50,26 & 9,72 & 3,11 & 1809,36 & 349,92 & 111,96 \\
\hline 12 & 0,01 & 0,25 & 35,92 & 9,45 & 2,51 & 898 & 236,25 & 62,75 \\
\hline$\Sigma$ & 2,03 & 1,35 & 10889,29 & 2997,61 & 1222,53 & 5783,7 & 1608,37 & 643,64 \\
\hline
\end{tabular}

Tabel 3. Miu Kuadrat Atribut Kurang Mampu

\begin{tabular}{|r|r|r|r|r|}
\hline \multirow{2}{*}{ No } & \multicolumn{1}{|c|}{$\mu^{2}$} & \multicolumn{3}{|c|}{} \\
\cline { 2 - 5 } & \multicolumn{1}{|c|}{ C3 } & \multicolumn{3}{|c|}{ Miu Kuadrat $X 3\left(\mu^{2} * X_{3}\right)$} \\
\hline 1 & 0,16 & 329,6 & 104,48 & 57,28 \\
\hline 2 & 0,04 & 155,32 & 61,04 & 31,2 \\
\hline 3 & 0,01 & 75,67 & 22,57 & 6,82 \\
\hline 4 & 0,09 & 263,43 & 109,53 & 104,67 \\
\hline 5 & 0,16 & 1283,52 & 218,88 & 71,52 \\
\hline 6 & 0,49 & 5615,4 & 1008,42 & 208,74 \\
\hline 7 & 0,09 & 538,47 & 191,16 & 75,15 \\
\hline
\end{tabular}




\begin{tabular}{|r|r|r|r|r|}
\hline \multirow{2}{*}{ No } & \multicolumn{1}{|c|}{$\mu^{2}$} & \multicolumn{3}{|c|}{} \\
\cline { 2 - 5 } & \multicolumn{1}{c|}{$C 3$} & \multicolumn{3}{|c|}{ Miu Kuadrat X3 $\left(\mu^{2} * \mathrm{X}_{3}\right)$} \\
\hline 8 & 0,04 & 116,44 & 28,76 & 14,68 \\
\hline 9 & 0,16 & 494,24 & 125,28 & 41,92 \\
\hline 10 & 0,25 & 931,5 & 212,5 & 58 \\
\hline 11 & 0,09 & 452,34 & 87,48 & 27,99 \\
\hline 12 & 0,16 & 574,72 & 151,2 & 40,16 \\
\hline$\Sigma$ & 1,74 & 10830,65 & 2321,3 & 738,13 \\
\hline
\end{tabular}

Berdasarkan hasil Tabel 2 dan Tabel 3, dengan menggunakan persamaan (3) dihitung pusat cluster (V) yang berasal dari total miu kuadrat dibagi total miu $X_{1}, X_{2}$ dan $X_{3}$ yang bisa dilihat pada Tabel 4 .

Tabel 4. Pusat Cluster

\begin{tabular}{|c|c|c|c|}
\hline Cluster & \multicolumn{3}{|c|}{ Pusat Cluster (V) } \\
\hline V1 & 5364,182266 & 1476,655172 & 602,23153 \\
\hline V2 & 4284,222222 & 1191,385185 & 476,77037 \\
\hline V3 & 6224,511494 & 1334,08046 & 424,21264 \\
\hline
\end{tabular}

Untuk selanjutnya $\mathrm{L}$ ditotal $(\Sigma \mathrm{L})$ keseluruhan untuk menemukan fungsi objektif (Pt). Pada iterasi pertama ini $\mathrm{P}_{\mathrm{t}}=39197408,65$. Menghitung LT dengan rumus persamaan :

$$
L T=\sum_{k=1}^{c}\left[\sum_{j=1}^{m}\left(X_{i j}-V_{k j}\right)^{2}\right]^{\frac{-1}{w-1}}
$$

Perhitungan LT untuk data pertama yaitu desa ngemplak:

$$
\begin{aligned}
L T & =\sum_{k=1}^{c}\left[\sum_{j=1}^{m}(11655677,3)^{2}\right]^{\frac{-1}{2-1}} \\
& =8,58 \mathrm{E}-08
\end{aligned}
$$

Dari persamaan (6) selanjutnya dihitung $\Sigma$ LT. Perhitungan Jarak Euclidean $\left(\mathrm{d}_{\mathrm{ik}}\right), \mathrm{L}$, dan

\begin{tabular}{|c|c|c|c|c|c|c|c|c|c|c|c|}
\hline No & \multicolumn{3}{|c|}{ Jarak Euclidean $\left(d_{i k}\right)$} & \multicolumn{3}{|c|}{$\mathbf{L}$} & \multirow{2}{*}{$\begin{array}{l}\text { Total L } \\
4371438,3\end{array}$} & \multicolumn{3}{|c|}{ LT } & \multirow{2}{*}{$\begin{array}{c}\begin{array}{c}\text { Total } \\
\text { LT }\end{array} \\
3,32 \mathrm{E}-07\end{array}$} \\
\hline 1 & 11655677,3 & 5251129,5 & 17811410,69 & 1049010,96 & 472601,7 & 2849825,711 & & $8,58 \mathrm{E}-08$ & $1,90 \mathrm{E}-07$ & $5,61 \mathrm{E}-08$ & \\
\hline 2 & 2227937,45 & 364894,554 & 5646093,831 & 200514,37 & 91223,64 & 225843,7532 & 517581,76 & 4,49E-07 & $2,74 \mathrm{E}-06$ & 1,77E-07 & 3,37E-06 \\
\hline 3 & 5467707,03 & 11954284,1 & 2720510,187 & 3499332,5 & 119542,8 & 27205,10187 & 3646080,4 & $1,83 \mathrm{E}-07$ & 8,37E-08 & $3,68 \mathrm{E}-07$ & $6,34 \mathrm{E}-07$ \\
\hline 4 & 6321739,49 & 2313619,38 & 11433096,65 & 1580434,87 & 92544,78 & 1028978,698 & 2701958,3 & $1,58 \mathrm{E}-07$ & $4,32 \mathrm{E}-07$ & $8,75 \mathrm{E}-08$ & $6,78 \mathrm{E}-07$ \\
\hline 5 & 7099897,88 & 14003061,8 & 3232634,727 & 1774974,47 & 140030,6 & 517221,5563 & 2432226,6 & $1,41 \mathrm{E}-07$ & $7,14 \mathrm{E}-08$ & $3,09 \mathrm{E}-07$ & $5,22 \mathrm{E}-07$ \\
\hline 6 & 37528013,2 & 52245385,6 & 27934402,59 & 1501120,53 & 522453,9 & 13687857,27 & 15711432 & $2,66 \mathrm{E}-08$ & $1,91 \mathrm{E}-08$ & $3,58 \mathrm{E}-08$ & $8,16 \mathrm{E}-08$ \\
\hline 7 & 856171,876 & 3883944,8 & 851046,934 & 77055,4688 & 621431,2 & 76594,22406 & 775080,86 & 1,17E-06 & 2,57E-07 & $1,18 \mathrm{E}-06$ & $2,60 \mathrm{E}-06$ \\
\hline 8 & 6647478,46 & 2120936,57 & 11360955,68 & 2393092,25 & 84837,46 & 454438,2272 & 2932367,9 & $1,50 \mathrm{E}-07$ & 4,71E-07 & $8,80 \mathrm{E}-08$ & $7,10 \mathrm{E}-07$ \\
\hline 9 & 5773369,33 & 1641460,93 & 10161434,95 & 923739,093 & 65658,44 & 1625829,591 & 2615227,1 & 1,73E-07 & $6,09 \mathrm{E}-07$ & $9,84 \mathrm{E}-08$ & $8,81 \mathrm{E}-07$ \\
\hline 10 & 3213409,23 & 488068,428 & 6513839,279 & 128536,369 & 43926,16 & 1628459,82 & 1800922,3 & $3,11 \mathrm{E}-07$ & $2,05 \mathrm{E}-06$ & 1,54E-07 & $2,51 \mathrm{E}-06$ \\
\hline 11 & 453859,89 & 625843,947 & 1580349,164 & 4538,5989 & 303,8 & 142231,4248 & 372073,84 & $2,20 \mathrm{E}-06$ & $1,60 \mathrm{E}-06$ & $6,33 \mathrm{E}-07$ & $4,43 E-06$ \\
\hline 12 & 3546650,79 & 590849,525 & 7111502,991 & 35466,5079 & 147712,4 & 1137840,479 & 1321019,4 & 2,82E-07 & $1,69 \mathrm{E}-06$ & $1,41 \mathrm{E}-07$ & $2,12 \mathrm{E}-06$ \\
\hline
\end{tabular}
LT dapat dilihat pada Tabel 5.

Tabel 5. Perhitungan Jarak Euclidean, L, dan LT

Kemudian hitung selisih fungsi objektif dengan mengurangi nilai fungsi objektif dengan iterasi sebelumnya. Untuk iterasi pertama dikurangi nol (0). Jika selisih $\left(P_{t}\right)$ fungsi objektif kurang dari eror terkecil yang diharapkan maka iterasi berhenti jika tidak, selanjutnya menghitung perubahan matriks derajat kenggotaan baru dengan persamaan (5).

Pada kasus ini iterasi berhenti pada iterasi ke 90 yang dihitung dengan Ms. Excel dan 30 pada sistem. Hasil perhitungan dapat dilihat pada Tabel 6 . Hasil yang diperoleh dari perhitungan 12 desa di Kecamatan yaitu cluster 1 terdiri dari 3 desa, cluster 2 terdiri dari 8 desa, dan cluster 3 terdiri dari 1 desa.
Tabel 6. Tabel perhitungan

\begin{tabular}{|l|l|c|c|c|c|c|c|}
\hline \multirow{2}{*}{$\begin{array}{l}\text { Data } \\
\text { ke- }\end{array}$} & \multirow{2}{*}{ Desa } & \multicolumn{3}{|c|}{ Derajat Keanggotaan dengan data } & \multicolumn{3}{|c|}{ Cluster ke- } \\
\cline { 3 - 8 } & & $\mathbf{1}$ & $\mathbf{2}$ & $\mathbf{3}$ & $\mathbf{C 1}$ & $\mathbf{C 2}$ & $\mathbf{C 3}$ \\
\hline $\mathbf{1}$ & Ngemplak & 0,05423670 & 0,92914347 & 0,016619 & & $*$ & \\
$\mathbf{2}$ & Gumpang & 0,06710026 & 0,92025150 & 0,012648 & & $*$ & \\
$\mathbf{3}$ & Makamhaji & 0,96337398 & 0,01558440 & 0,021041 & $*$ & & \\
$\mathbf{4}$ & Pabelan & 0,03503857 & 0,95612040 & 0,008841 & & $*$ & \\
$\mathbf{5}$ & Ngadirejo & 0,87900566 & 0,04182171 & 0,079172 & $*$ & & \\
$\mathbf{6}$ & Kartasura & 0,00013078 & $3,5984 \mathrm{E}-05$ & 0,999833 & & & $*$ \\
$\mathbf{7}$ & Pucangan & 0,82500893 & 0,13494937 & 0,040041 & $*$ & & \\
$\mathbf{8}$ & Kertonatan & 0,01041907 & 0,98686313 & 0,002717 & & $*$ & $*$ \\
$\mathbf{9}$ & Wirogunan & 0,00613997 & 0,99232194 & 0,001538 & & $*$ & $*$ \\
$\mathbf{1 0}$ & Ngabeyan & 0,01992630 & 0,97583326 & 0,004240 & & $*$ & $*$ \\
$\mathbf{1 1}$ & Singopuran & 0,34566905 & 0,60981335 & 0,044517 & & $*$ & $*$ \\
$\mathbf{1 2}$ & Gonilan & 0,01039307 & 0,98733907 & 0,002267 & & $*$ & \\
\hline
\end{tabular}




\subsection{Usecase Diagram}

Usecase Diagram pada aplikasi sistem pemetaan daerah berpotensi transmigran di Kecamatan Kartasura dimulai dari BPS (Badan Pusat Statistik) Kabupaten Sukoharjo melakukan pencatatan data statistik penduduk, kemudian melakukan proses pemetaan daerah berpotensi transmigran dengan data yang sudah ada, sehingga menghasilkan data pemetaan daerah berpotensi transmigran dengan algoritma Fuzzy C-Means. Tampilan gambar dapat dilihat pada Gambar 2.

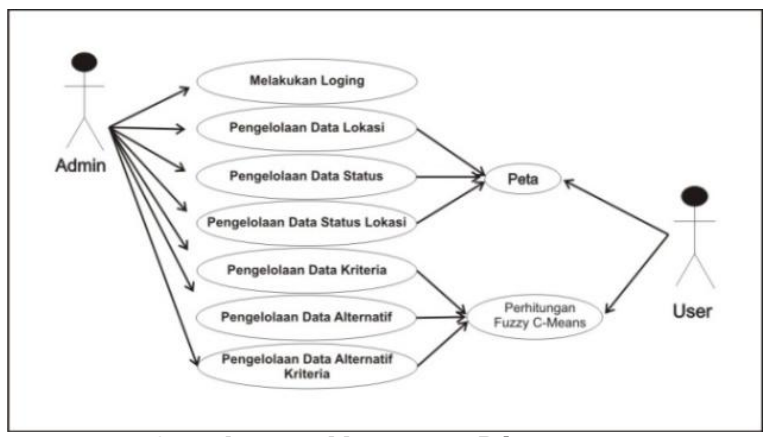

Gambar 2. Usecase Diagram

\subsection{Implementasi}

Implementasi dari sistem pemetaan daeah berpotensi transmigran di kecamatan kartasura dapat dilihat sebagai berikut.

\section{a. Tampilan Beranda}

Pada tampilan awal beranda akan muncul pemetaan daerah berpotensi transmigran di kecamatan kartasura yang tampil berdasarkan kecamatan dan daerah yang berpotensi atau tidak. Setiap kecamatan akan muncul keterangan jika di klik dan sudah dikelompokkan daerah berpotensinya berdasarkan warna. Keterangan warna sudah ditampilkan dibawah peta. Tampilan beranda dapat dilihat pada Gambar 3.

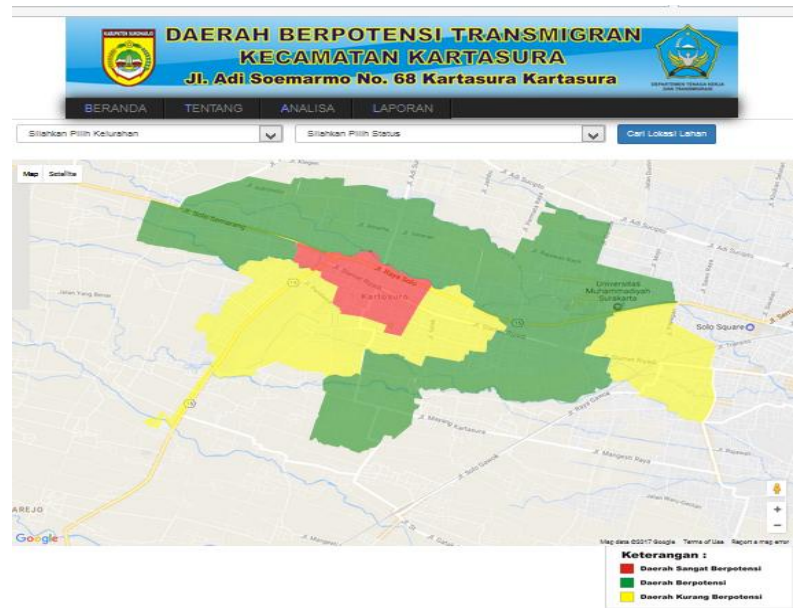

Gambar 3. Tampilan Beranda

\section{b. Analisa}

Analisa berisi tentang pengolahan data nilai alternatif dan kriteria yang kemudian sistem melakukan perhitungan dengan menggunakan metode fuzzy c-means. Proses analisa akan berjalan an muncul hasilnya setelah di klik tombol proses. Analisa akan menghasilkan angka da daerah mana yang berpotensi transmigran. Tampilan menu analisa dapat dilihat pada Gambar 4.

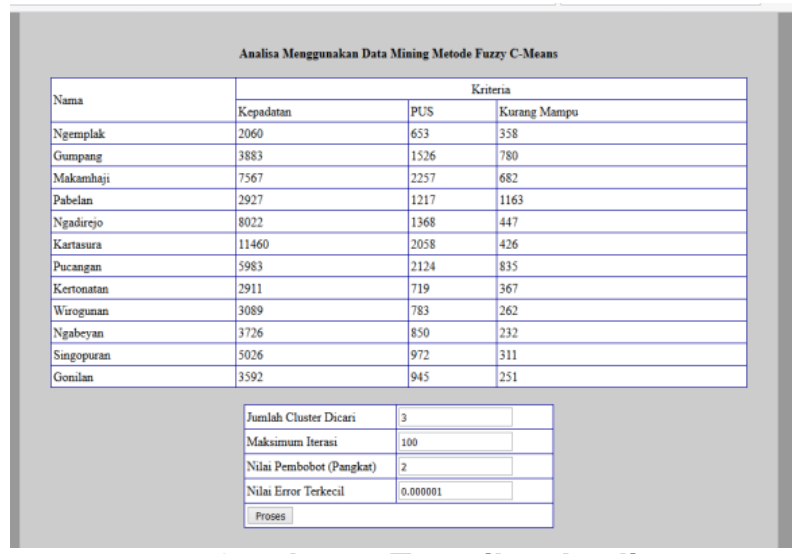

\section{Gambar 4. Tampilan Analisa}

c. Laporan

Laporan berisi tentang hasil status daerah yang berpotensi transmigran beserta alamat lokasi. Tampilan laporan dapat dilihat pada Gambar 5.

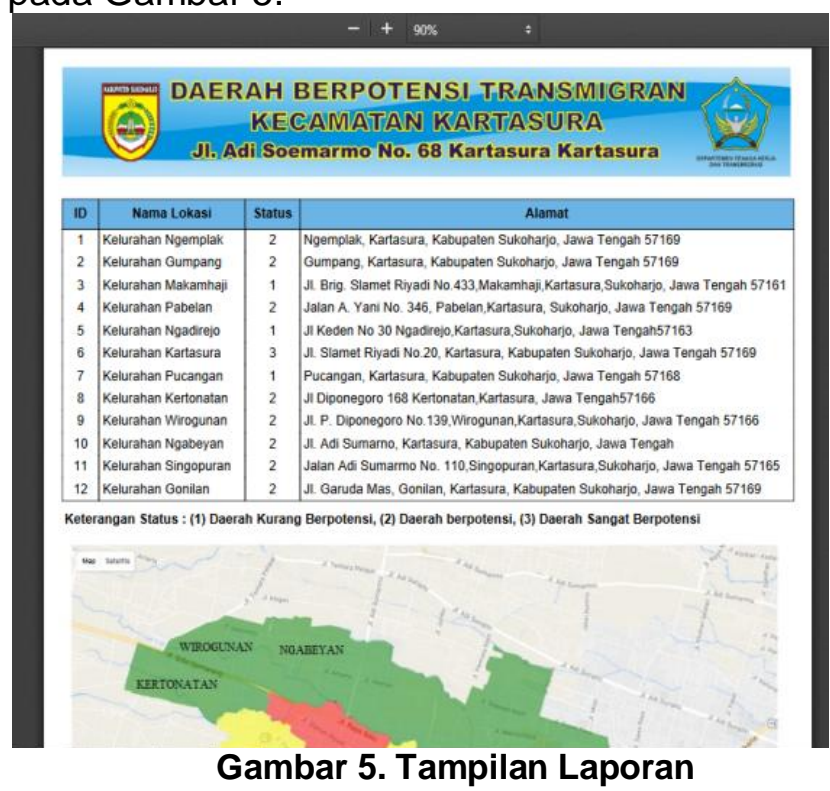

d. Halaman Admin

Pada halaman ini admin dapat melakukan input semua data yang ada pada sistem yaitu data lokasi, data status, data status lokasi, data kriteria, data alternatif dan data alternatif kriteria. Berikut ini salah satu tampilan data lokasi yang dapat dilihat pada Gambar 6. 


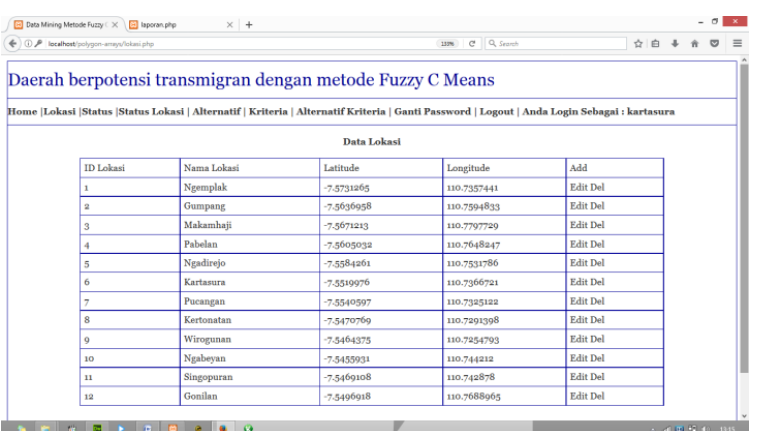

Gambar 6.Tampilan Data Lokasi

Pada halaman data admin dapatmenambah data, edit data, hapus datadan melihat data lokasi.

\subsection{Pengujian Sistem}

Uji coba fungsional sistem dengan Blackbox untuk mengetahui bila terjadi kesalahan atau kekurangan sehingga sistem yang dibuat dapat diperbaiki untuk menghasilkan sistem sesuai yang diharapkan.

Untuk pengujian validasi hasil cluster, digunakan metode modified partition coefficient (MPC). MPC merupakan metode yang digunakan untuk menguji validitas jumlah cluster. MPC sendiri merupakan pengembangan dari metode partition coefficient (PC). Partition coefficient (PC) merupakan metode yang mengukur jumlah cluster yang mengalami overlap. Nilai PC berada dalam batas $\frac{1}{c} \leq P C(c) \leq 1$. Pada umumnya jumlah cluster yang paling optimal ditentukan dari nilai $P C$ yang paling besar $\left(\max _{2 \leq c \leq n-1} P C(c)\right)$. Berikut adalah algoritma metode PC pada persamaan (7) :

$$
P C(c)=\frac{1}{N} \sum_{i=1}^{c} \sum_{j=1}^{N}\left(\mu_{i j}\right)^{2}
$$

$$
\text { Partition coefficient }
$$

cenderung

mengalami perubahan yang monoton terhadap beragam nilai c (jumlah cluster). Modifikasi dari indeks PC (Modified Partition Coefficient / MPC) dapat mengurangi perubahan yang monoton tersebut. Nilai MPC berada dalam batas $0 \leq \mathrm{PC}(\mathrm{c}) \leq 1$. Pada umumnya jumlah cluster yang paling optimal ditentukan dari nlai MPC yang paling besar ( $\max _{2} \leq \mathrm{c} \leq \mathrm{n}-1 \mathrm{PC}(\mathrm{c})$ ). Berikut adalah algoritma metode MPC pada persamaan (8) :

$$
\operatorname{MPC}(\mathrm{c})=1-\frac{\mathrm{c}}{\mathrm{c}-1}(1-\mathrm{PC}(\mathrm{c}))
$$

Dimana:

$\mathrm{C}=$ jumlah cluster

MPC $(c)=$ nilai indeks MPC pada cluster ke-c. Pengujian Validasi
Pengujian validitas cluster menggunakan metode Modified Partition Coefficient (MPC). Tiap periode data diuji.tingkat validitas dengan jumlah cluster tiga sampai lima. Periode data yang digunakan yaitu tahun 2014 dan 2015 . Untuk data 2014 bisa dilihat pada Tabel 1 sedangkan data 2015 dilihat pada Tabel 7.

Tabel 7. Data Alternatif Kriteria tahun 2015

\begin{tabular}{|c|l|r|r|r|}
\hline \multirow{2}{*}{ No } & \multirow{2}{*}{\begin{tabular}{c} 
Desa / \\
\cline { 3 - 5 }
\end{tabular}} & Alternatif & \multicolumn{3}{|c|}{ Parameter } \\
\cline { 3 - 5 } & Ngemplak & 2107 & 681 & $\begin{array}{c}\text { Krg } \\
\text { Mampu }\end{array}$ \\
\hline 2 & Gumpang & 3972 & 1693 & 764 \\
\hline 3 & Makamhaji & 7645 & 2304 & 695 \\
\hline 4 & Pabelan & 2947 & 1266 & 1167 \\
\hline 5 & Ngadirejo & 8088 & 1396 & 451 \\
\hline 6 & Kartasura & 11475 & 2089 & 438 \\
\hline 7 & Pucangan & 6102 & 2187 & 837 \\
\hline 8 & Kertonatan & 2972 & 745 & 379 \\
\hline 9 & Wirogunan & 3116 & 798 & 269 \\
\hline 10 & Ngabeyan & 3732 & 864 & 236 \\
\hline 11 & Singopuran & 5095 & 999 & 313 \\
\hline 12 & Gonilan & 3656 & 971 & 255 \\
\hline
\end{tabular}

Pengujian validasi cluster dengan menghitung $\mathrm{PC}(\mathrm{c})$ menggunakan persamaan (7) dan menghitung MPC(c) dengan persamaan (8) Penjelasan tentang tingkat validitas jumlah cluster akan dijelaskan pada Tabel 8.

\section{Tabel 8. Tabel Validasi Cluster}

\begin{tabular}{|c|c|c|c|}
\hline Periode & 3 Cluster & 4 Cluster & 5 Cluster \\
\hline 2014 & 0,802850401 & 0,702014266 & 0,676917534 \\
\hline 2015 & 0,793020335 & 0,702423097 & 0,671580778 \\
\hline
\end{tabular}

Nilai dari indeks MPC berkisar antar 0 sampai 1 . Tingkat validitas tertinggi dimiliki oleh jumlah cluster dengan indeks MPC tertinggi. Pada periode data 2014 dan 2015 menunjukan bahwa jumlah cluster dengan indeks MPC tertinggi dimiliki oleh jumlah cluster 3. Maka dapat disimpulkan bahwa melakukan klasifikasi data daerah berpotensi transmigran di Kecamatan Kartasura menjadi 3 cluster merupakan validasi tertinggi.

\subsection{Perbandingan Sistem Lama dengan Sistem yang Diusulkan \\ Perbandingan sistem lama yang telah berjalan beserta sistem yang akan diusulkan adalah sebagai berikut:}


a. Sistem Lama

- Kinerja : Sistem pengolahan dengan aplikasi SPPS. Namun, aplikasi ini hanya bisa digunakan oleh user yang mengerti tentang pengolahan data statistik.

- Informasi : Software menyajikan data dilakukan secara terperinci.

- Ekonomi : Software SPPS ini merupakan aplikasi berbayar.

- Keamanan: Pada proses penyimpananya belum menggunakan database.

- Efisiensi : Pada pengunaan software SPPS harus menunggu orang yang bisa menggunakan selain itu software inipun hanya dimiliki oleh badan transmigrasi dan tenaga kerja pusat karena bersifat berbayar.

b. Sistem Baru

- Kinerja : Sistem pengolahan data menggunakan sistem daerah berpotensi transmigran dan mudah digunakan oleh bagian administrasi hanya dengan penjelasan singkat.

- Informasi : Sistem menyajikan data dalam bentu peta dan analisis perhitungan menggunakan Fuzzy C-Means.

- Ekonomi : Sistem daerah berpotensi transmigran bisa diakses dengan gratis.

- Keamanan: Penyimpanan data daerah berpotensi transmigran sudah menggunakan database sehingga mudah dikontrol dan ditingkatkan keamanannya.

- Efisiensi : Pada penggunaan sistem daerah berpotensi transmigran data baru hanya butuh di input selanjutnya melakukan analisis data dan akan keluar hasil analisis beserta pemetaanya.

\section{PENUTUP}

\subsection{Kesimpulan}

Pada pembuatan sistem pemetaan daerah berpotensi transmigran di kecamatan kartasura dengan metode Fuzzy C-Means (FCM) Clustering yang telah dibahas dapat disimpulkan sebagai berikut:

1. Metode fuzzy c-means dapat diterapkan pada pemetaan daerah berpotensi transmigran di Kecamatan Kartasura.

2. Perhitungan hasil cluster dipengaruhi oleh nilai variabel data alternatif kriteria beserta nilai cluster.

3. Pengujian validasi cluster dengan data alternatif kriteria pada periode data tahun 2014 dan tahun 2015 menyatakan bahwa 3 cluster merupakan validasi cluster yang cocok.
4. Pada penelitian pemetaan daerah berpotensi transmigran di Kecamatan Kartasura ini menghasilkan cluster $1=3$ desa, cluster $2=8$ desa, dan cluster $3=1$ desa.

\subsection{Saran}

Adapun saran yang ingin penulis sampaikan adalah sebagai berikut :

1. Sistem ini dibuat sesuai dengan kebutuhan dalam pemetaan darah berpotensi transmigran di lingkup Kecamatan, diharapkan sistem ini dapat menangani ukuran atau jumlah yang besar sehingga dapat diterapkan di lingkup yang lebih besar seperti kantor kabupaten dan sejajarnya.

2. Perlu dilakukan proses penggalian variasi variabel data alternatif kriteria agar hasil clustering yang dihasilkan dapat lebih maksimal.

3. Sistem yang telah dibuat melakukan clustering dengan hasil lingkup desa, diharapkan hasil clustering mampu dikembangkan dalam lingkup yang lebih kecil yaitu per KK atau Kepala Keluarga agar pencarian transmigran lebih tepat dan mudah.

4. Sistem yang telah dibuat masih cukup sederhana karena lebih mengutamatakan inti dari proses perhitungan fuzzy c-means.

\section{DAFTAR PUSTAKA}

[1] Sudrajat, "Analisa Potensi Calon Transmigran Sasaran Pengarahan dan Perpindahan," MGI, vol. 22, no. 19, pp. 125-144, September 2008.

[2] A. K. Wijaya, "Data Mining dengan Algoritma Fuzzy C-Means Studi Kasus Penjualan di UD Subur Baru," Fasilkom Udinus, pp. 1-8, 2014.

[3] A. H. Setianingrum, "Model Pemetaan Evaluasi Penilaiaan Kualifikasi Lulusan Berbasis Metode Fuzzy C-Means Clustering," Jurnal Tehnik Informatika, vol. 7, pp. 8-15, Oktober 2014.

[4] Martin J. Bunch, T. Vasantha Kumaran, R. Joseph, "Using Geographic Information System (GIS) For Spatial Planing and Environmental Management India," International Journal of Applied Science and Tecnology, vol. 2, pp. 40-54, February 2012.

[5] Yinghua Lu, Tinghuai Ma, Changhong, Xiaoyu Xie, Wei Tian, Shui Ming Zhong, "Implementation Of The Fuzzy C-Means 
Clustering Algorithm in Meteorologi Data," International Journal of Database Theory and Application, vol. 6, pp. 1-18, 2013.

[6] K. Nasution, "Definisi, Fungsi, Komponen, dan Jenis-jenis alat dalam Pemetaan," PETA, 2016. [Online]. Available: http://kurnia12.blogspot.co.id/2016/03/peta-definisifungsi-komponen.html. [Diakses 19 Desember 2016].

[7] H. Heeren, Transmigrasi di Indonesia (terjemahan oleh Hans Daeng dan Willie Koen)., Jakarta: PT Gramedia, 1979.

[8] Sri Kusumadewi, Hari Purnomo, Aplikasi Logika Fuzzy Untuk Pendukung Keputusan, Yogyakarta: Graha IImu, 2004.

[9] Jun Yan, Micheal dan James Power, Using Fuzzy logic (Toward Intelligent System), New York: Prentice-Hall.

[10] R. Pressman, Software Engineering: A Practitioner's Approach, 7th ed. Mc Grow Hill, 2010. 